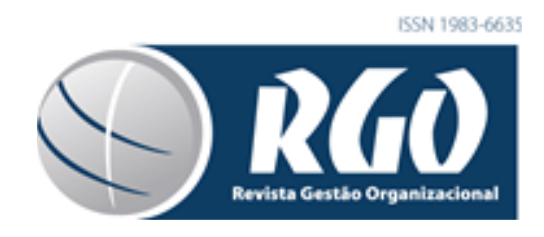

EDIÇÃO ESPECIAL: COMEMORATIVA AOS 45 ANOS

DOS CURSOS DE GRADUAÇÃO EM

\title{
SITUATIONAL LEADERSHIP AND THE ORGANIZATIONAL LIFE CYCLE: CASE STUDY IN A PATRONAL UNION
}

\author{
LIDERANÇA SITUACIONAL E O CICLO DE VIDA ORGANIZACIONAL: \\ ESTUDO DE CASO EM UM SINDICATO PATRONAL
}

\begin{abstract}
MATIAS TREVISOL
Faculdade Senac e UNETRI - União de Ensino da Trifronteira - Mestre em Administração Orcid: http://orcid.org/0000-0002-9939-9570 / E-mail: matias.trevisol@gmail.com

FERNANDO FANTONI BENCKE

Universidade do Oeste de Santa Catarina - Doutor em Administração

Professor e Pesquisador da Universidade do Oeste de Santa Catarina (Unoesc)

Orcid: http://orcid.org/0000-0001-9721-3173 / E-mail: fernando.bencke@unoesc.edu.br

Endereço: Av. Nereu Ramos, 3777-D - Bairro Seminário - Chapecó - SC - CEP 89813-000

LUCCAS SANTIN PADILHA

Universidade do Oeste de Santa Catarina - Doutorando em Administração

Orcid: http://orcid.org/0000-0002-5786-3259 / E-mail: luccas_santin@hotmail.com

\section{DARLAN JOSE ROMAN}

Universidade do Oeste de Santa Catarina - Doutor em Administração

Professor do PPG em Administração da Universidade do Oeste de Santa Catarina

Orcid: http://orcid.org/0000-0002-2004-8736 / E-mail: darlan.roman@unoesc.edu.br
\end{abstract}

\begin{abstract}
SUMMARY
Studies involving the topics of organizational life cycle and situational leadership institutions in the third sector, as a union, was little explored in the literature. Moreover, recent changes in the Brazilian legislation brought new challenges to these organizations. This study seeks to fill these gaps, to analyze the role of leadership and organizational life cycle in a company union, linking theories against the employers' association. The metaphor of the organization life cycle allows the analysis of organizations at different stages and, consequently, the role of leadership in the development of courses. The research was qualitative, used methods of case study and oral history, and descriptive and exploratory. Data collection used documental analysis, non-participant observation and in-depth interviews with seven leaders who experienced the historical trajectory of the institution. Among the main contributions of this study, it stands out as a theoretical contribution, the association of situational leadership theories and the organizational life cycle in a union representation institution, still little explored in the literature. Among the practical contributions highlight the situational leadership as alternative for sustainability for organizational cyclic life of a union, which now depend on its resources and internal management capabilities for their survival.
\end{abstract}

Keywords: Situational leadership. Organizational life cycle. Employers' association. Third sector.

Data de submissão: 07/11/2019. Data de aceite: 30/11/2019. Data de publicação: 17/12/2019.

Artigo selecionado no fast track do COGECONT - International Conference in Management and Accounting, realizado na Universidade Comunitária da Região de Chapecó - Unochapecó, Chapecó - SC, de 17 a 19/10/2019.

RGO - Revista Gestão Organizacional, Chapecó, v. 12, n. 3, Edição Especial, p. 35-53, 2019.

ISSN 1983-6635 
EDIÇÃO ESPECIAL: COMEMORATIVA AOS 45 ANOS DOS CURSOS DE GRADUAÇÃO EM

CIÊNCIAS CONTÁBEIS E ADMINISTRAÇÃO DA UNOCHAPECÓ

\section{RESUMO}

Estudos envolvendo os temas ciclo de vida organizacional e liderança situacional em instituições do terceiro setor, como sindicato, foi pouco explorado pela literatura. Além do mais, mudanças recentes na legislação brasileira trouxeram novos desafios a essas organizações. Esse estudo busca preencher essas lacunas, ao analisar o papel da liderança e o ciclo de vida de organizacional em um sindicato patronal, associando as teorias frente ao sindicato patronal. A metáfora do ciclo de vida das organizações permite a análise das organizações em diferentes etapas e, consequentemente, o papel da liderança no desenvolvimento dos ciclos. A pesquisa foi qualitativa, utilizados métodos de estudo de caso e história oral, e de caráter descritivo e exploratório. A coleta de dados utilizou análise documental, observação não participante e entrevistas em profundidade com sete lideranças que vivenciaram a trajetória histórica da instituição. Dentre as principais contribuições deste estudo, destaca-se como contribuição teórica, a associação das teorias liderança situacional e o ciclo de vida organizacional em uma instituição de representação sindical, ainda pouco explorado na literatura. Dentre as contribuições práticas destaca-se a liderança situacional como alternativa de sustentabilidade para o clico de vida organizacional de um sindicato, que passou a depender de seus recursos e capacidades internas de gestão para sua sobrevivência.

Palavras-chave: Liderança situacional. Ciclo de vida organizacional. Sindicato Patronal. Terceiro setor.

\section{INTRODUCTION}

Classical approaches to leadership often are focused on striking figures, as conquerors and military leaders. Currently, new approaches and reflect the historical, political and cultural leadership phenomenon (GLASER; STAM; TAKEUCHI, 2016; TURANO; CAVAZOTTE, 2016).

In this context, we study the theory of Situational Leadership (TLS) proposed that there is a correct leadership style, or more appropriate, rather, behavior characteristics of leaders and followers in line with the situation (CHAPMAN, 2018; GRAEFF, 1997; OSBURNE, 1990; THOMPSON; VECCHIO, 2009; Wright, 2017). In this approach, the leadership may or may not be effective depending on the situation where they are inserted leaders and followers, as well as their behavioral characteristics (CHAPMAN, 2018; SHRIVER; WILLIAMS, 2019; SMITH, 1991). For Osburne (1990), leadership occurs if the leaders know the characteristics of his followers, thus being able to adjust their behavior to exercise leadership, influencing the social environment and the cycle of life in organizations.

In turn, Adizes (1990) addresses the role of people in development organizations, from the stages of growth and even aging, which calls the theory of organizational life cycle. Leaders have a fundamental role in the development of these phases, due to its distinct features (ADIZES, 1990; Li, 2019; SILVA; EMMENDOERFER, 2013).

Unions have representation in Brazil, has a development history linked to political, business and workers, who built and legislated in search of rights of the represented categories guarantees. It highlights the importance of such leadership for implementation and implementation of Brazilian trade unionism throughout its historical context (PINTO, 2007). 
EDIÇÃO ESPECIAL: COMEMORATIVA AOS 45 ANOS DOS CURSOS DE GRADUAÇÃO EM CIÊNCIAS CONTÁBEIS E ADMINISTRAÇÃO DA UNOCHAPECÓ

The approval of Law 13,467 of July 2017 is a new scenario and new challenges for unions in Brazil. Due to the end of compulsory union dues, the representation of entities needs to create new forms of fundraising and innovate to remain sustainable and survive at the moment changes in labor legislation.

This study aims to analyze the role of situational leadership and organizational life cycle in a company union, seeking to relate the theories. Using the organizational metaphor of growth and aging organizations, it is an analytical tool that allows you to analyze how the union, studied, developed phases of its life cycle and how the leaders worship different leadership styles depending on the level development of the followers and the organization.

Thus, the study of situational leadership in the context of a company union becomes relevant, since a representation institution has its bases in the people who lead (POCHMANN, 1998; SHRIVER; WILLIAMS, 2019; WRIGHT, 2017) and they are responsible for their future.

Among the main contributions of this study, it stands out as a theoretical contribution to rapprochement between situational leadership and organizational life cycle in a union representation institution, still little explored in the literature (SANTANA, 2015). Among the practical contributions highlight the situational leadership as alternative for sustainability for organizational cyclic life of a union, which now depend on its resources and internal management capabilities for their survival.

Regarding the methodological procedures, the research approach is qualitative with descriptive approach and methods of case study and oral history for data collection was conducted desk research, interviews and non-participant observation.

In this introduction, the second part presents the literature review, the third part are marked methodological procedures in the fourth part of the data and discussion are presented in the fifth closing remarks are presented.

\section{SITUATIONAL LEADERSHIP, ORGANIZATIONS OF LIFE CYCLE AND THE UNION IN BRAZIL}

The Situational Leadership Theory (TLS) was first proposed by Hersey and Blanchard at Ohio University in 1968. The TLS addresses not only the role that the leader must play as well, the leading elements, follower and the situation (CHAPMAN, 2018; ROLOW, JOHN, 2009; SHRIVER; WILLIAMS, 2019; WRIGHT, 2017).

As Osburne (1990) TLS has aimed to prepare the leader to perform a certain task in different contexts, by promoting changes in leadership styles on the characteristics of followers and different situations. For Shriver and Williams (2019), there is no leadership style considered correct but different leadership styles that take into account characteristics of leaders and followers, and different situations.

The situational leadership model seeks to value the followers, so the leadership must be exercised using different leadership styles depending on the members and the situation (BERGAMINI, 2006; GONÇALVES; MOTA 2011, SHRIVER; WILLIAMS, 2019), which promotes the study of TLS with the life cycle of Adizes organizations (1990).

The first studies on the life cycle of organizations (CVO) are dated 1950 and sought to understand the development of organizations. They can be used in small and large businesses, and adapted for organizations formats such as cooperatives, unions and NGOs (SANTANA, 2015). The CVO models are based on metaphors to describe the development of the organizational life 
EDIÇÃO ESPECIAL: COMEMORATIVA AOS 45 ANOS DOS CURSOS DE GRADUAÇÃO EM CIÊNCIAS CONTÁBEIS E ADMINISTRAÇÃO DA UNOCHAPECÓ

cycle. According Morgan (2009), the metaphor is used in the social sciences to describe real events and compare them to mental models to facilitate understanding, based on a partial reality, a way to understand the concepts of reality and organize thoughts through an abstraction in which certain features are emphasized and others suppressed in a selective comparison (MORGAN, 2009).

Organizations go through problems, conflicts and difficulties during his career. In each of the organization's life stages, problems can occur, especially in times of leadership transition, of business segment or process changes (MANZARDO et al., 2018; SILVA; JESUS; MELO, 2010).

According to the model of Adizes (1990), the life cycle of organizations is divided into: dating; infância; preadolescent (touch-touch); adolescence; fullness; stability; aristocracy; incipient tape; and paperwork; death. Each phase has distinct characteristics where you can see the role of leadership as well as their strategies and structure for growth. According to Adizes (1990), organizations at the beginning of their life cycle, are flexible, but not always controllable. As the organizational life cycle develops, this relationship changes, the control increases and the flexibility decreases, appearing thus other important relationships, such as the role of leadership for further development.

In the historical context of trade unionism in Brazil it is possible to analyze the life cycle of these entities that lasted over the years, and its ability to perpetuity. In the historical trajectory of the company union, Lopez (2012) points out that the employer representation goes through a time of fragmentation and reduction of standing. Prior to the 1988 constitution, the number of unions in Brazil proved exaggerating, and grew abnormally and scary. Currently, the reality is different with the approval of Law 13,467 of July 2017, due to the end of compulsory union dues, and the need to be self-sufficient and sustainable.

According to Adizes (1990) organizations are in the aging process, which is the case for many Brazilian unions, it is necessary to understand each stage of the life cycle, to analyze the need for change and the role of leadership. In this context, situational leadership helps in understanding the causes and effects, embodied every situation.

Regarding the Brazilian trade union context, the leader who operates in this segment needs to be flexible, according to a union is a representative institution, which becomes different than a traditional organization. The way decisions are made, the exchange of knowledge, information and opinions with peers have less rigid characteristics than in traditional organizations (CAIRNS et al., 1998; GRAEFF, 1997; LI, 2019; MANZARDO et al., 2018; OSBURNE, 1990; SMITH, 1991).

Thus, there are the research presented in this study on the theory of situational leadership, where there is no appropriate leadership style for a given situation, but leaders who know how to change their behavior from the characteristics of his followers and the situation (CAIRNS et al., 1998; GRAEFF, 1997; OSBURNE, 1990; SMITH, 1991; SHRIVER; WILLIAMS, 2019; THOMPSON, VECCHIO, 2009; WRIGHT, 2017).

So how leaders behave in the development life cycle is crucial for decision-making at different stages of the union, which reflects the actions taken and its continuity. In this bias, the leaders have different styles of leading, as the life cycle develops the different leaders adopted different behaviors and styles from each other, which is evident in the analysis of TLS (OSBURNE, 1990). 
EDIÇÃO ESPECIAL: COMEMORATIVA AOS 45 ANOS DOS CURSOS DE GRADUAÇÃO EM

CIÊNCIAS CONTÁBEIS E ADMINISTRAÇÃO DA UNOCHAPECÓ

\section{METHODOLOGY}

In order to clarify the choice of the object of study, the trade union employer carries out actions to foster the economy of Chapecó and region, mainly through the representation of the employer category and in the different activities for the trade companies. By 2018, it had approximately 7,500 associates in 25 municipalities in the west of Santa Catarina. It also develops orientation, professionalization, research, occupational medicine and dental plans initiatives with member companies, with the objective of strengthening and integrating the program with its members in the regional community.

Another point referring to the patronal union, which as of 2016 began to offer products, services, benefits and to advise member companies, offering operational support. Often these services and benefits are offered by workers unions, however, adopted differentiated strategies from other national employer unions.

Regarding the methodological procedures, the research approach is qualitative, with a descriptive approach and methods case study (YIN, 2015) and oral history (DENZIN, 1989). Among the selection criteria of the union object of study, there is the time of existence and representation in the segment in which it operates. The union trade segment has approximately 50 years, and about 7,500 member companies.

The method of oral history, according to Ferreira (1998) history is a set of procedures that begins with the preparation of an interview protocol and definition of persons to be interviewed alongside written documents to, images and other types of records. Evidence sources consulted for this study were documents, interviews and observation not participants.

The institution's documents were analyzed such as the minutes of decision-making meetings, ownership of minutes, bylaws, union letter, city newspapers for news and information of the institution. The in-depth interviews were conducted with the aid of a script that contained a central statement about the history of the union, following a few topics to support research, embodied the categories of analysis. We used the method of triangulation (case study and oral history), theory (Situational leadership and organizational life cycle), data (documents, interviews and non-participant observation) and researchers (authors of this study), as proposed by Patton (2002).

They interviewed seven subjects experienced the historical trajectory of the union and the development of its life cycle, as follows: President of the current administration; two leaders of previous administrations; two executive directors of the current administration; vice president and current management; Press officer. The interviews were conducted from September 2017 to May 2018. As can be seen from Table 1.

Table 1 - Research Subjects

$\begin{array}{ccc}\text { Main function performed } & \text { Union time* } & \text { Duration } \\ \text { Executive Director F } & 8 \text { years } & 2 \text { hours } \\ \text { Chief Financial Officer F } & 12 \text { years } & 1 \text { hour } 15 \text { minutes } \\ \text { President B } & 6 \text { years } & 1 \text { hour and } 10 \text { minutes } \\ \text { President D } & 7 \text { years } & 1 \text { hour } \\ \text { Press Officer F } & 2 \text { years } & 1 \text { hour and } 20 \text { minutes } \\ \text { President F } & 10 \text { years } & 30 \text { minutes } \\ \text { Vice President F } & 7 \text { years } & 1 \text { hour }\end{array}$

*Union time refers to time not only in office but added to previous functions.

Source: prepared by the authors (2019). 
EDIÇÃO ESPECIAL: COMEMORATIVA AOS 45 ANOS DOS CURSOS DE GRADUAÇÃO EM

CIÊNCIAS CONTÁBEIS E ADMINISTRAÇÃO DA UNOCHAPECÓ

As the data analysis technique was used content analysis (BARDIN, 2011) as an analytical a priori categories: (1) union life cycle - organizational life cycles, Growth, Aging and historical trajectory of the union; (2) Leadership and Leadership Style. Before the investigation, it was possible to identify significant points in the trajectory and life cycle, and in the course of analysis emerged the need to incorporate the Leadership Theory Situational so elencando retrospectively the third category (3) Situational Leadership in Life Cycle union - organizational life cycles, leadership styles, situation and trajectory history of the union.

The research analyzed the development of union life cycle of 1970-2018, based the theory of the life cycle of organizations Adizes (1990) and the analysis of the behavior of leaders and followers (members) throughout the development cycle Union life, based on the Situational Leadership Theory Hersey and Blanchard (1986) and Blanchard (2011). Following the discussions and main results are presented.

\section{DISCUSSION AND RESULTS}

In this section are presented and analyzed data from field research, starting with the description and analysis of the union's life cycle, the leadership styles that make up the TLS based on the narratives of the subjects and, finally, were approached and analyzed the topics that make up this study, and the results achieved.

The employers 'association study takes action in order to stimulate the economy in its catchment area, mainly through the representation of employers' category and in the different activities for the companies trade. It currently has approximately 7,500 members in 25 municipalities, also develops, guidance initiatives, professional, research, occupational health and dental plan with business associates, with the strengthening of order and integrating the union and its members to the regional community. It is responsible for representing different areas as the distributor sector, wholesale and retail.

The organization was founded in 1970, with the initial intention of assisting entrepreneurs trade in labor negotiations, collective agreements and the relationship between employers and employees segment. It is currently a reference in the segment of trade and is one of the largest trade associations of their status.

The study was possible to identify each of the stages described by Adizes (1990), with the initial phase of dating, where the organization is only an idea, the founders dream, think and plan, but nothing is put into practice. The founder is in a state of euphoria and enthusiasm to put into practice his idea, predicting the results that will in the future at that time only the founder is convinced that his dream can be reality and committed efforts to convince the other members, is a now a lot of talk and little action (ARAÚJO; ARAÚJO, 2015).

It was possible to demonstrate the courtship when, in the 1970s, according to the report of the respondents, there was a city of growth and, consequently, the expansion of trade. Traders of the time felt the need to organize due to the increase in customer traffic, sales and service, and they felt unprotected in relation installment sales, a modality that came true at the time. As reported by respondents $A$ and $B$ : 
EDIÇÃO ESPECIAL: COMEMORATIVA AOS 45 ANOS DOS CURSOS DE GRADUAÇÃO EM CIÊNCIAS CONTÁBEIS E ADMINISTRAÇÃO DA UNOCHAPECÓ

The city was growing and we saw the opportunity of the employers' association, ... the city grew and traders have also begun to negotiate more. Had customers from other regions coming here, then we founded the union. (EXECUTIVE DIRECTOR F).

In 1970, the businessmen of the time, with the situation and the need to provide the employer union representation here in the city, then began to organize themselves in order to form a union [...] They first formed an association of retail trade, and this association has to deal with matters relating to commercial / economic category (CHIEF FINANCIAL OFFICER F).

Entrepreneurs gathered to protect the existing default and founded a Shopkeepers Camera (CDL) of the city. The idea was that this entity auxiliasse in the movement flow and access to credit, avoiding damage to entrepreneurs. Even with the foundation of CDL, traders realized that the performance of the entity was not enough to increasing demand that had been created in the trade of the city. The account of the respondent shows this: "The city grew and traders have also started to negotiate. The number of consumers from other regions who came here to Chapeco increased, we founded the CDL which is linked to the credit sales, provide customer information all these things (EXECUTIVE DIRECTOR F).

At that point the union of the life cycle is notorious entrepreneurial idea of putting in place an institution that not only acted in aprazo sales, but that mediate labor relations between traders and workers. The idea of the institution to be put into practice, more usually follows the intuition of the founder than a deliberate planning for it (MANZARDO et al., 2018; SILVA; EMMENDOERFER, 2013).

Similarly, the idea of putting into practice the union was dormant since the workers were organized and represented about negotiating salary and working hours among other entities related to professional practice in the trade. The negotiation between the labor union and traders was made by the Trade Federation that had headquarters in the state capital. However, the city, due to the economic flow and the feature of commerce, had features that were not the same experienced in the state capital, which often brought problems in the agreements with the workers, as mentioned Interviewee A: "When I was to adjust or set the salary, the time came nearly ready the capital. We think that, in this situation we decided to establish our union,

Based on the testimonies, companies trade needed greater autonomy for the use of its workforce, as regards labor relations. This is why there is the need for union representation to defend the interests of traders and to lead negotiations with the workers and the labor union.

To Adizes (1990), the commitment to the idea is being internalized by the founder himself andAt the same time, experienced by others. The more the idea is sold, the firmer becomes his own commitment to the idea of having determines institution. To make a commitment at this stage, the founder may make promises which can not meet (ARAÚJO; ARAÚJO, 2015; MANZARDO et al., 2018.).

As testimony of the Respondent who experienced this phase, it was necessary to create a professional association of retail trade in the city, to then be transformed into union. Normally, professional associations lingered many years to become union. The transition to the union took only two years due to the need and the association's relationship with political leaders.

Thus, this phase of the life cycle of the union, its main characteristic is the dream of trade leaders to put in place a company union on trade in the city. The courtship is characterized entrepreneur's dream to put a functioning institution and the possibility of putting into practice 
EDIÇÃO ESPECIAL: COMEMORATIVA AOS 45 ANOS DOS CURSOS DE GRADUAÇÃO EM CIÊNCIAS CONTÁBEIS E ADMINISTRAÇÃO DA UNOCHAPECÓ

the business desires. There is a possibility that dream is affected as the troubleshooting solve the embodiment (DE CARLI; VASCONCELOS; LEZANA, 2014).

In sequence the union enters the stage of childhood, that the metaphor of the life cycle of organizations Adizes (1990), makes an analogy between organizations and child development. According to the author, the pediatric organizations are children, and this institutional feature makes these face risks to keep in operation and prevent infant mortality. The role of the founder of this stage of development is to awaken the commitment to your dream (ADIZES, 1990).

In this regard, according to the Respondent A and B, March 1972 with the operating permit of the Retail Union, the first board was elected and the union began operating in the city, particularly in the negotiations relating to work in the trade, schedules, wages and agreements between traders and employees.

Like this, Li said (2019), the founder has focused on the production and not in the market, which is the result of emotional commitment to the idea and the performance of the product is what motivates the entrepreneur to take risks. It relies on the idea and have confidence that it is an opportunity for growth and is not interested in what the market needs.

Hein, Beuren and Novello (2011) state that in the childhood phase, the institution has few or no formal control system. Your system of managing is usually precarious, missing records, there are few meetings, and decisions are highly centralized in the figure of the founder (or founders). While the decisions are centralized in the founding, the institution is aware of complaints from stakeholders in order to meet their needs (DE CARLI; VASCONCELOS; LEZANA, 2014; LI, 2019).

Therefore, an organization ceases to be a child and goes to the next stage of the life cycle when its cash situation, their activities and their modus operandi begin to stabilize. The founders have time to think about the proper management, can delegate more tasks at the institution and what is developed is no longer centered on your figure (ADIZES, 1990; ARAUJO, ARAUJO, 2015).

In the third phase of the pre-adolescence employer's union life cycle, the idea of its creation can already be seen in practice, cash flow is in positive status, and the institution can put in place more actions than ever before. The number of members grows, the union can engage entrepreneurs depending on their modus operandi, they realize that the institution is a reality of their surroundings, they can view the union as a potential for the collective development of companies in the trade. The institution is not only living longer blooming, which causes the leaders at this stage to see everything as potential business, it is a time of growth (ADIZES, 1990; MANZARDO et al., 2018; SILVA; EMMENDOERFER, 2013).

In the late 1990s, viewing the opportunity of buying a new space for the union headquarters, the leaders together with business associations, acquired a complex of buildings that was owned by the Bank of Brazil. That moment became significant and model for other cities to provide the interaction of the three entities linked to trade in the same space, as stated by the Chief Financial Officer F: "The purchase of the complex was a landmark ... very important in the institutional and business process the city because it was the moment that consolidated the institutional representation of the business class. "(CHIEF FINANCIAL OFFICER F).

According to Adizes (1990) at this stage of organizational development, the institutions that had to run behind profitability, can not see other opportunities in the market. Becoming organizations driven by opportunities, not organizations generating opportunities. Board members think of focus which are having profitability, acting the way they realized that capture more members, reacting to the operating environment, not paying attention to plan the RGO - Revista Gestão Organizacional, Chapecó, v. 12, n. 3, Edição Especial, p. 35-53, 2019. 
EDIÇÃO ESPECIAL: COMEMORATIVA AOS 45 ANOS DOS CURSOS DE GRADUAÇÃO EM

CIÊNCIAS CONTÁBEIS E ADMINISTRAÇÃO DA UNOCHAPECÓ

environment where you want to invest and operate (DE CARLI; VASCONCELOS; LEZANA, 2014; HEIN; BEUREN; NOVELLO, 2011).

The union has been growing and developing, depending on the quality of products and services offered to members and how drove the agreements and conventions of working. Also, by how it related to the labor union and how was the working relationships between traders and their employees.

During this period, the union begins to expand it territorial base, create new products, services and implement existing ones. With the expansion of the territorial base beyond the city of its headquarters, the union grew in membership and, consequently, the demand for products, services and actions of the institution increased, demanding that leaders behave in order to meet the new time.

According to Adizes (1990) at this stage of development, the functions are not well separated in practice. The person responsible for purchasing, is also the one who sells, the counter works part time as a manager, for example. The institution is organized around people and not the tasks and grow in an unplanned way. The institution reacts to opportunities rather than plan, organize or position yourself for future opportunities that will create.

Thus, the president realizes that needs organization with previous experience I see where you are hitting and where is missing at this stage is when the institution realize you need to deploy control systems, both in finance, as in people for jobs They are made with higher quality, always seeking to associate satisfaction (HEIN; BEUREN; NOVELLO, 2011; SILVA; EMMENDOERFER, 2013).

At this stage called adolescence is called when the institution is reborn. She has gained wide practical experience in the market segment and follows without the control of the founder who had hitherto. The authority begins to be delegated and is not centered only on one member. This rebirth is painful and longer than the birth of the institution, at this stage of organizational development the institution is able to maintain and create without much effort as in the earlier stages (ADIZES, 1990; HEIN; BEUREN; NOVELLO, 2011; MANZARDO et al., 2018).

In 1986, he assumed the presidency of the union leadership who played the role of founder when the union was just a dream in courtship. He was president of the city's Retail Association and moved entrepreneurs of the time for the creation of the union.

During the phase of the life cycle, the union renewed its leaders and the second president was elected, the board began implementing new practices the union. It is then that the union begins to professionalize its members, through training courses, lectures, technical visits to get to know other realities and the provision of services to members such a legal advice. It is noticed that the renewal of the leadership was very important for the organization, its members have internalized the renewal of leadership.

At this stage of the life cycle, the institution conquer its independence, expanding the horizons to new markets, new areas of activity and new partnerships, letting go of its founder, thinking of a less traditional way risking more for the new, which can lead to conflict difficult management of the new with the old management. The main difficulty consists in accepting some leaders to leave the institution move alone (ADIZES, 1990; ARAUJO, ARAUJO, 2015; FERREIRA; AZEVEDO; CROSS 2008; MANZARDO et al., 2018.).

At this point there was a milestone in the transition from adolescence to fullness, the most favorable point on the curve of the organizational life cycle. The institution won the self-balance and flexibility, have knowledge about what you are doing, where you want to go and how to RGO - Revista Gestão Organizacional, Chapecó, v. 12, n. 3, Edição Especial, p. 35-53, 2019.

ISSN 1983-6635 
achieve the goal. In the fullness, the organization has a competitive budget, it is an organization that has the aggressiveness of a touch-touch, but maintains predictability and control acquired in adolescence (FERREIRA; AZEVEDO; CROSS, 2008; HEIN; BEUREN; NOVELLO 2011; SILVA; EMMENDOERFER, 2013; MANZARDO et al., 2018).

During this period the union life cycle, there is an important and strategic moment for the development and positioning of the institution. After the change of presidency in 2004, the union produced its first strategic plan, which was considered important to define the largest investment areas as hued President F: "The first time management was a moment that has already implemented a first strategic planning of the organization was in 2004 ... which was conducted with directors effective planning process of construction" (PRESIDENT F).

The vitality of an institution at the stage of fullness is incremented by the momentum generated in the dating stage, put to the test in childhood, reactivated in stage plays-plays, institutionalized and channeled in adolescence and is capitalized to the fullest. But that is when the institution must return the drive to not lose their entrepreneurial spirit and not park and become obsolete (ADIZES, 1990).

After the period of fullness, starts the period of stability. Stability the company is still strong, however, it loses its flexibility it had previously, reaches the end of growth and begins to decline (ADIZES, 1990). At this stage, the union has strategically defined the following ways. In a new change in the presidency, the union creates a different look to social issues, a period considered to be very important to the institution by the resumption of political power in state institutions trade. President $F$, the institution changed the focus that had previously and began to also act on the causes of society, such as public safety:

We had to there unite in 2014, claim to make you change the structure of our policies so
that 3 or 4 years after we are today, we are not in an ideal scenario, but we are with a
very good security scenario compared with other cities. We have a declining crime rate,
how does that happen? Occurred because the authorities fought there in 2014. [...] in
conjunction with the business, it was the society as a whole, this meant that the police
had to integrate and better quality. This is better for the trader is best for society, it is an
example of what we did (PRESIDENT F).

Phase Stable, according to the organizational life cycle model Adizes (1990), is the first aging stage. At that stage the institution starts to exhibit some features such as: loss of creative spirit, innovation and encouraging the changes that led to the fullness (FERREIRA; AZEVEDO; CROSS, 2008). The life cycle, as well as their characteristics, can be seen in Figure 1. 
Figure 1 - Cycle of organizational life of the union and its main features

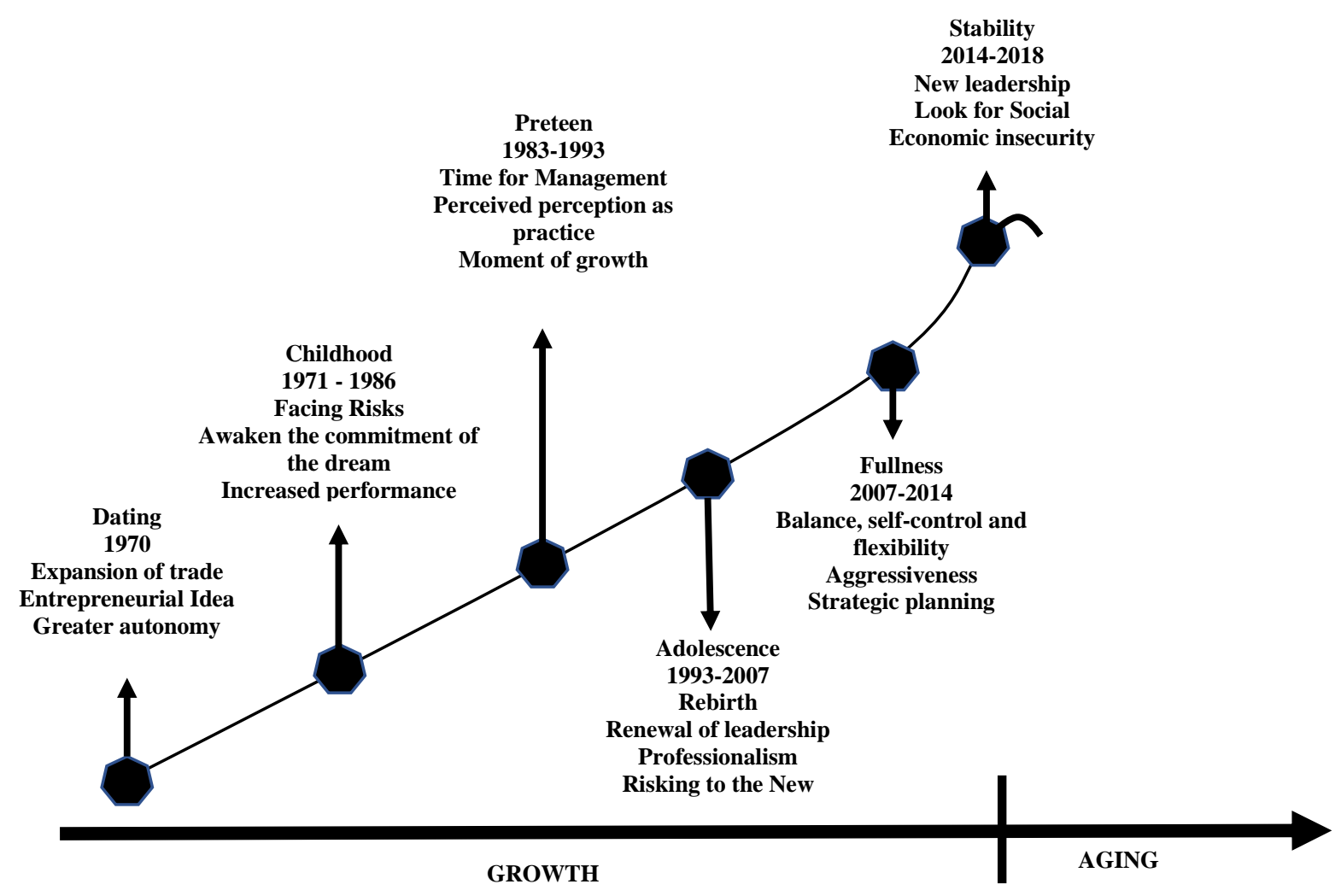

Source: prepared by the authors (2019) based on Adizes (1990).

The institution is also focused on the results and still held at that time she has won a stable position in the market and acquired a sense of security that may prove unfounded in the long run. The creativity and sense of urgency are present, but often ephemeral way. The atmosphere becomes more formal, but still hear new ideas and enthusiasm of other phases disappears (ADIZES, 1990).

It was possible to show that the union under study is in the stability phase. An alert that is evident in this phase, the institution begins to lose flexibility and accommodate is a stage marked by the end of growth and the beginning of the decline. The institution has earned a stable position in the market which makes its members feel safe in relation to the positioning of the institution, becoming more conservative, less flexible, more formal and less aggressive as in previous stages (ADIZES, 1990).

\section{4 .1 LEADERSHIP SITUATION AND UNION LIFE CYCLE}

During the development of the union's life cycle, it is clear that the leaders played a key role in its development. The distinguishing characteristics of each leader contributed to the positioning of the institution. It is noticed also, that the way decisions were made throughout history, created favorable moments of credibility associated, increasing profitability and moving the trade sector. 
EDIÇÃO ESPECIAL: COMEMORATIVA AOS 45 ANOS DOS CURSOS DE GRADUAÇÃO EM CIÊNCIAS CONTÁBEIS E ADMINISTRAÇÃO DA UNOCHAPECÓ

In life cycle analysis union through the Adizes of metaphor (1990), we can see based on the narratives of the subjects and in other sources of evidence, according to the steps of the cycle have been developed and the union grew, putting into practice products and services, increasing the number of followers (associates), the leaders were taking leadership styles theory of situational leadership (BLANCHARD, 2011; CHAPMAN, 2018; HERSEY; BLANCHARD; 1986; SHRIVER; WILLIAMS, 2019).

On the TLS considered follower development level andFrom that, the leader adapts it their behavior as the appropriate style (BLANCHARD, 2011; CHAPMAN, 2018; GLASER; STAM; TAKEUCHI, 2016; SHRIVER; WILLIAMS, 2019; WRIGHT, 2017). According Harsey and Blanchard (1986), the TLS has the idea that the leader will assist the maturation of their followers until they are able to develop particular task or adopt certain desired behavior by the leader.

In this sense, it is clear that at the beginning of the union life cycle, followers were not developed or lacked maturity, did not understand what the union would play, had doubts about joining the proposal. It was necessary for the leader to adopt a leadership style able to change this condition develop followers on the understanding of the institution so that they act as boosters of the idea of being associated.

As Blanchard (2011), followers need direction, are considered excited beginners. The leader needs to have a high degree of managerial behavior and low level of support behavior, followers need direction can not yet put into practice their ideas, or even understand how to give your interest in the entity, since their level of development and knowledge of the institution's function is very low, need the leader to direct its operations and consequently their behavior (BLANCHARD et al., 2011; CHAPMAN, 2018, SHRIVER; WILLIAMS, 2019).

According Harsey and Blachard (1986), the TLS maintains that the followers underdeveloped or immature, need a firm direction, which is the governing behavior that leaders must use, to become more productive. They also suggest that as the development of followers is necessary that the leading reward for positive reinforcement and support emotional partner, ie support behavior that the leader needs to adopt. The leader must motivate, encourage and praise instigating followers as your expectation for that moment (GLASER; STAM; TAKEUCHI, 2016; SOUZA; GOLDEN, 2016; WRIGHT, 2017).

As the life cycle union was developing, the institution was put into practice by offering new products and services, and with the increasing number of members, the leaders adopted new leadership styles. With the development of followers in relation to knowledge and understanding of the business of the institution, on its practical function, performance and likewise the products and services that the union has offered throughout the development life cycle, the leaders of the union adopted new behaviors and, consequently, new leadership styles.

In this case, an alternative presidency after many years indicates the need to change the position in relation to the members, seeking to reverse the non-satisfaction of the members of the previous term. According to Blanchard (2011), the purpose of the leader should be to help his follower to improve their performance through the gradual change of leadership style. For the leader to develop the four leadership styles described by TLS, you need to go through all the styles from E1 to E4 (GLASER; STAM; TAKEUCHI, 2016; SOUZA, GOLDEN, 2016; WRIGHT, 2017).

It is noticed that the developmeent of leadership styles, as proposed by the model of TLS, appear throughout the development of the union's lifecycle. To change the reality of the institution requires of leaders, act differently with their followers. With the new reality of the RGO - Revista Gestão Organizacional, Chapecó, v. 12, n. 3, Edição Especial, p. 35-53, 2019. 
EDIÇÃO ESPECIAL: COMEMORATIVA AOS 45 ANOS DOS CURSOS DE GRADUAÇÃO EM CIÊNCIAS CONTÁBEIS E ADMINISTRAÇÃO DA UNOCHAPECÓ

institution, the leaders have adopted different behaviors, since throughout the development followers now have low competence and low performance (SHRIVER; WILLIAMS, 2019; ROLOW, JOHN, 2009).

In this case, it is evident that the union leaders have taken a self-supporting degree, being present with the members, promoting their participation and raising more people to join the institution. The leaders also adopted a steering behavior, through the professionalization of the members, through services offered as specific demands, for example, to promote agreements between members and their delinquent customers. Thus, entrepreneurs could develop while union members, along with the development of the entity (BRANCHARD et al., 2011; CHAPMAN, 2018; HARSEY; BRANCHARD, 1986; SHRIVER; WILLIAMS, 2019).

It is notorious through the narratives of respondents the union has a particularity in terms of leadership. The institution is not like a traditional organization, where the alternating presidency or board is not common. The characteristic of the union leadership is that the chair is switched in the electoral process.

The alternation of the union leadership, the presidential candidates are always people who already work on the board in leadership positions, either on specific boards that represent each segment of trade, or in other leadership positions. In this sense, the presiding officer, already has experience as a leader in the institution, however the union does not have a formal training program for leaders.

It is evident that leaders care about development of trade and associated companies. It is noticed that each leader has a way to lead different, but everyone fit their behavior, always facing the acceptance of followers to the new proposals suggested. As Blanchard (2011), the situational leader is premised on the idea that followers can and want to grow, and that there is no best leadership style than the other to encourage growth, but that the application of style leadership must be tailored to each specific situation.

Another feature of the union leadership is that presidents are leading business trade mostly manage the company itself which requires different styles of leadership. In union leaders have certain followers, members of the organization, which are not the same for your business. In the case of the origin company of the leaders, the followers are the employees and other members of the company.

In this regard, when questioned about this particular, the majority of respondents reported that divided the roles played your business with a family member, or employees, due to the peculiarities and demands required by the presidency of the union activities. According to them, the union plays a more political role in order to participate in events, representing the entity receiving the demands of the members, chair the meetings that are held agreements and taken the entity's decisions, and all paperwork.

Another evidenced remarkable event is the need to adopt new leadership characteristics, in view of the new cycle of life begins. The current scenario of trade unions demand situational leaders who operate new forms of leadership in pursuit of sustainability of the institution. With the end of compulsory union dues, the leader of the institution needs to act strongly on the innovation of the products and services, to attract members and nonmembers for the benefits that the organization can offer them.

In this sense, it is clear that the union leaders had this view for a long time. They realized that the union should offer more robust products and services to meet effectively the members. RGO - Revista Gestão Organizacional, Chapecó, v. 12, n. 3, Edição Especial, p. 35-53, 2019. 
Thus, the leaders encouraged the development of followers in the different situations that the institution has over the development of their life cycle and caused the union to become a reference for the other trade associations in the state. In this way we analyze the characteristics of union leaders as the adopted leadership style based on TLS in Table 2.

Table 2 - Leadership styles and main highlighted features.

\begin{tabular}{c|l}
\hline leadership style & Main features \\
\hline \multirow{3}{*}{ Direction } & $\begin{array}{l}\text { More evident in the early stages of the union; } \\
\text { The leader directed the behavior of followers; } \\
\text { The leader directed the followers of the importance of the union. }\end{array}$ \\
\hline Sentoring & $\begin{array}{l}\text { Followers already know the importance of the entity; } \\
\text { High degree of direction and support; } \\
\text { Period with little change of leadership; } \\
\text { Leader oversees the behavior of followers. }\end{array}$ \\
\hline \multirow{5}{*}{ Delegation } & $\begin{array}{l}\text { Çlaughed new ideas to the institution without the leader need to direct } \\
\text { their behavior; } \\
\text { The leader provides the security that previously was swinging; } \\
\text { The leader works in the strengthening of actions and projects that provide } \\
\text { this to associate. }\end{array}$ \\
\hline $\begin{array}{l}\text { Followers besides knowing the institution become more demanding when } \\
\text { it offers; } \\
\text { Level of development of high followers over the previous phases; } \\
\text { Followers is able to assume greater responsibility than before; } \\
\text { It is still the leader who identifies the problem, the responsibility of } \\
\text { executing the project is of followers. }\end{array}$
\end{tabular}

Source: Prepared by the authors (2019), based on Blanchard (2011).

The union had throughout their life cycle, situational leaders who helped to develop products, services and benefits that were responsible for the development and sustainability of the institution, which reinforces the role of situational leadership in a dynamic environment of constant change in which are unions in Brazil. To contextualize the association of theories in the employer trade union, a graphical representation developed by associating the life cycle and situational leadership theory, showing the election and re-election of each of the presidents and leadership styles prevalent in each phase as shown in Figure 2. 
Figure 2 - Cycle of organizational union life and situational leadership style and presidents

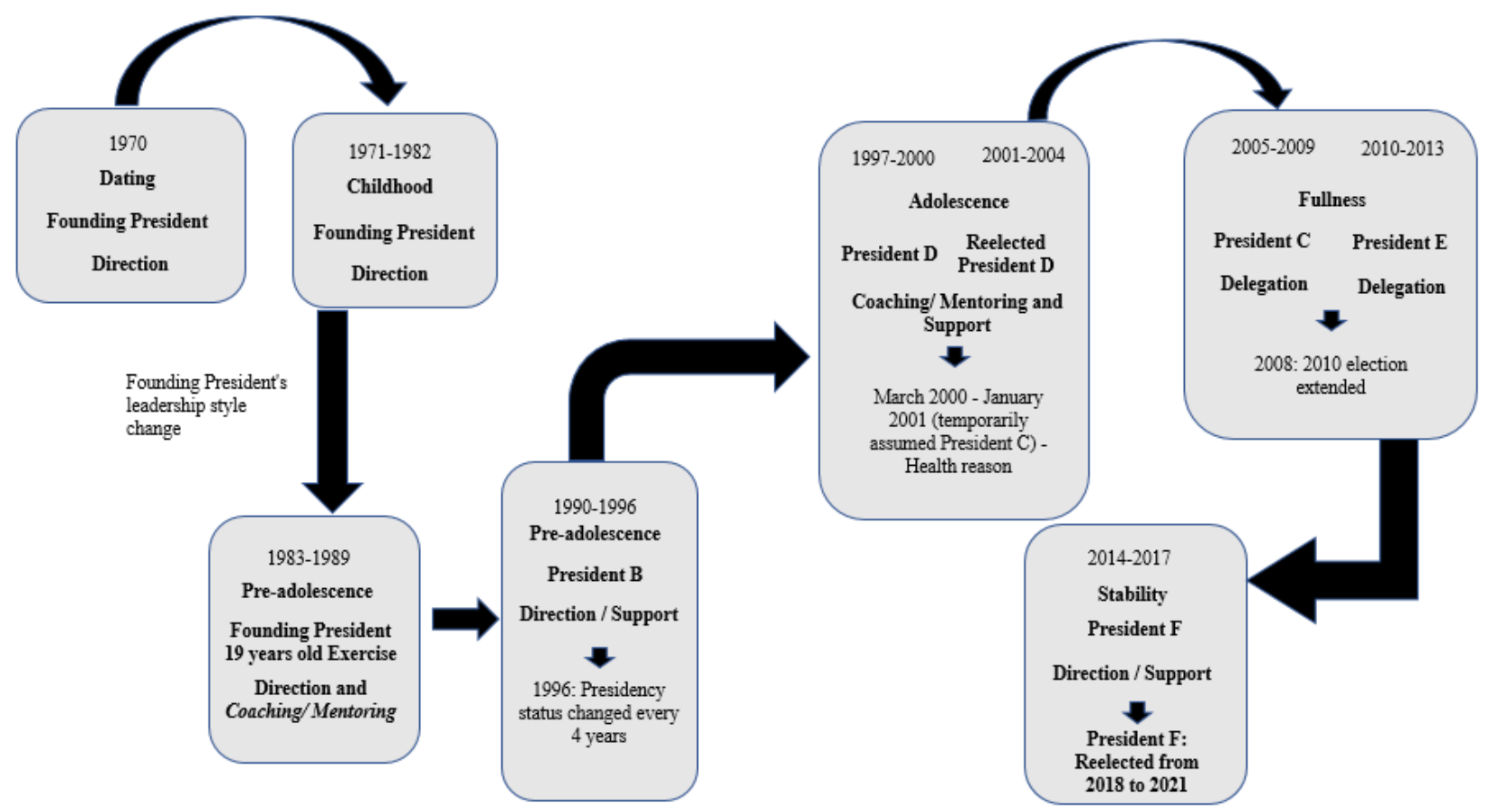

Source: prepared by the authors (2019).

However, it can be seen, that in each phase of the cycle there was a predominant style leader, which allows seeing the leading characteristics of each cycle. It is noteworthy that in the union's founding, the stage was just beginning, over time we sought a design that allowed new leaders, and consequently new leadership styles. However, in the year 2017 with the withdrawal of compulsory union dues, there is a semblance of leadership reflected with its founding characteristics, so policy, seeking opportunities for new form of fundraising.

\section{FINAL CONSIDERATIONS}

When analyzing the development of the union's life cycle showed up elements that make leadership relations with different characteristics from other organizations. Because it is an organization of the third sector, in which presidents are elected, the social relations between leaders and followers are influenced.

Given the objective of analyzing the leadership and union life cycle due to new phases of the life cycle that the institution achieves, it is evident the need of leadership styles proposed by TLS.

Identifies that the union has the following phases of the life cycle, as Adizes (1990): dating, childhood, play, teens, fullness and currently as analysis of the institution through the metaphor of the union is in phase stability. Stability second Adizes (1990) is the first phase of organizational aging.

According to the theory of situational leadership Harsey and Blanchard (1986) and Blanchard (2011), the leader adopts certain style of leadership that makes up the TLS as the interaction between the row and the situation. Throughout the development of this study, it is 
EDIÇÃO ESPECIAL: COMEMORATIVA AOS 45 ANOS DOS CURSOS DE GRADUAÇÃO EM CIÊNCIAS CONTÁBEIS E ADMINISTRAÇÃO DA UNOCHAPECÓ

noted that the styles of TLS were adopted over the union's life cycle, with the development and maturation of followers. Such phases of the cycle were predominant styles of leadership, which includes the objective of this study is to analyze the life cycle and TLS, associating theories.

As the development or maturation of union members, participating in the actions proposed by the institution and interacting with it, it is clear that the leaders adopt behaviors TLS for situations experienced along the historic union trajectory and hence the development of organizational life cycle. Thus, the analysis of TLS with the metaphor of the life cycle of organizations Adizes (1990), allow us to realize the behavior of leaders in the face of situations experienced during the union's development.

Knowing the union life cycle and situational leadership has great impact on the sustainability of the entity and its leaders can prepare for situations that the union will experience. This research does not claim to exhaust the subject, studies in other settings using the theories, association concepts can enrich the studies on leadership and life cycle of organizations.

A limitation of this research mentions the difficulty of interviewing some subjects of the union, being active entrepreneurs in their organizations and have commitments inherent in its operations management, it was difficult agenda.

Among the main theoretical and empirical contributions of this study, there is a closer relationship between situational leadership and organizational life cycle in a union representation institution, still little explored in the literature, and there is the situational leadership as alternative for sustainability for I click the organizational life of the union, which now depend on its resources and internal management capabilities to its continuity.

Thus, it is expected that the techniques and theories used throughout the development of this research can assist the union in its development and can contribute just as other organizations. And as a suggestion for future studies, motivate new studies and aimed to investigate the relationship between organizational life cycle and situational leadership.

\section{REFERENCES}

ADIZES, Ichak. Corporate lifecycles: How and why corporations grow and die and what to do about it. Prentice Hall, Nova Jersey,1990.

BERGAMINI, Cecília Whitaker. Motivação nas organizações. São Paulo: Atlas, 2006.

BLANCHARD, Ken. Liderança de alto nível: como criar e liderar organizações de alto desempenho. Tradução de Rosalia Neuman Garcia. Porto Alegre: Bookman, 2011.

CAIRNS, Thomas D; Hollenback, John.; Preziosi, Robert; Snow, William.A study of Hersey and Blanchard's situational leadership theory. Leadership \& Organization Development Journal, Londres, v. 19, n. 2, p. 113-116, 1998.DOI: https://doi.org/10.1108/01437739810208692

CHAPMAN, Ann LN. An introduction. In: Medical Leadership. Routledge, 2018. p. 59-60. 
EDIÇÃO ESPECIAL: COMEMORATIVA AOS 45 ANOS DOS CURSOS DE GRADUAÇÃO EM CIÊNCIAS CONTÁBEIS E ADMINISTRAÇÃO DA UNOCHAPECÓ

DE ARAUJO, Danilo Henrique Petrillo Pires; DE ARAUJO, Tatiane Regina Pires. Análise do ciclo de vida organizacional: estudo em empresas familiares no Distrito Federal. Universitas: Gestão e TI, Brasilia, v. 5, n. 2, 2015. DOI: 10.5102/UN.GTI.V5I2.3552

DE CARLI, Eduardo; VASCONCELOS, Alexandre Meira; LEZANA, Álvaro Guillermo Rojas. Conhecimentos e habilidades de comunicação para empreendedores nas fases iniciais do ciclo de vida organizacional de Adizes. Revista de Negócios, Blumenau, v. 19, n. 2, p. 21-35, 2014.DOI: http://dx.doi.org/10.7867/1980-4431.2014v19n2p21-35

DE SOUZA, Marcos José Cosme; DOURADO, Débora Coutinho Paschoal. Estilo de liderança: o caso de uma empresa de serviços/leadership style: the case of a company of services. RAUnP São Paulo, v. 8, n. 2, p. 34-47, 2016. DOI: http://dx. doi. org/10.21714/raunp

DENZIN, Norman Kent. Interpretive biography. New York, Sage, 1989.

EMMENDOERFER, Magnus Luiz; SOARES, Érica Beranger Silva; VALADARES, Josiel Lopes; SILVA, Fernanda Cristina. Um panorama das políticas públicas de turismo no Estado de Minas Gerais, Brasil, no período de 1999 a 2014. XVIII Congreso Internacional del CLAD sobre la Reforma del Estado y de la Administración Pública, Montevideo, Uruguay, 29 oct. - 1 nov., 2013.

FERREIRA, João José Matos; AZEVEDO, Susana Garrido; DA CRUZ, Maria Rosa Pires. A logística e o processo de crescimento das organizações: a teoria do ciclo de vida. Panorama

Socioeconómico, São Bento do Sul, n. 36, p. 206-220, 2008.

FERREIRA, Marieta de Moraes. Desafios e dilemas da história oral nos anos 90: o caso do Brasil. Revista de História Oral, São Paulo, n. 1, p. 19-30, 1998.

GLASER, Lotte; STAM, Wouter; TAKEUCHI, Riki. Managing the risks of proactivity: A multilevel study of initiative and performance in the middle management context. Academy of Management Journal, New York, v. 59, n. 4, p. 1339-1360, 2016.DOI:

https://doi.org/10.5465/amj.2014.0177

GONÇALVES, Helen Silva; DE MIRANDA MOTA, Caroline Maria. Liderança situacional em gestão de projetos: uma revisão da literatura. Production, São Paulo, v. 21, n. 3, p. 404-416, 2011. DOI: https://10.1590/S0103-65132011005000046

GRAEFF, Claude L. Evolution of situational leadership theory: a critical review. The Leadership Quarterly, Lausanne, v. 8, n. 2, p. 153-170, 1997. DOI: https://doi.org/10.1016/S10489843(97)90014-X

HEIN, Nelson; BEUREN, Ilse Maria; NOVELLO, Aliciane Aparecida. Sistema classificador híbrido do ciclo de vida organizacional. Revista de Administração da UNIMEP, Piracicaba, v. 9, n. 2, p. 123, 2011. 
EDIÇÃO ESPECIAL: COMEMORATIVA AOS 45 ANOS DOS CURSOS DE GRADUAÇÃO EM CIÊNCIAS CONTÁBEIS E ADMINISTRAÇÃO DA UNOCHAPECÓ

HERSEY, Paul; BLANCHARD, Kenneth. Psicologia para administradores: a teoria e as técnicas da liderança situacional. In: Psicologia para administradores: a teoria e as técnicas da liderança situacional. Epu, 1986.

LAURENCE, Bardin. Análise de conteúdo. Tradução de Luís Antero Retos, Augusto Pinheiro.São Paulo: Edições, v. 70, 2011.

LI, Hui. Leadership succession and the performance of nonprofit organizations: A fuzzy-set qualitative comparative analysis. Nonprofit Management and Leadership, New York, v. 29, n. 3, p. 341-361, 2019. DOI: https://doi.org/10.1002/nml.21339

LOPEZ, Daniel, Mansur. Respostas estratégicas dos sindicatos patronais do comércio de bens, serviços e turismo do Brasil às pressões institucionais. 2012. 12 p. Dissertação (Mestrado em Administração - Escola Brasileira de Administração Pública, Rio de Janeiro, 2012.

MANZARDO, Alessandro; LOSS, Andrea; JINGZHENG, Ren; ZULIANI, Filippo; SCIPIONI, Antonio.Definition and application of activity portfolio and control/influence approaches in organizational life cycle assessment. Journal of cleaner production, Amsterdã, v. 184, p. 264273, 2018. DOI: https://doi.org/10.1016/j.jclepro.2018.02.262

MORGAN, Neil.; VORHIES, Douglas.; MASON, Charlotte. Market orientation, marketing capabilities, and firm performance. Strategic management journal, New Jersey, v. 30, n. 8, p. 909-920, 2009. DOI: https://doi.org/10.1002/smj.764

OSBURNE, Andrea. Situational leadership and teacher education. Pergamon Press, New Britain, v. 17, n. 3, p.409-420, 1990. DOI: https://doi.org/10.1016/0346-251X(89)90014-6

PATTON, Michael Quinn. Two decades of developments in qualitative inquiry: A personal, experiential perspective. Qualitative social work, New York, v. 1, n. 3, p. 261-283, 2002. DOI: https://doi.org/10.1177/1473325002001003636

PINTO, Almir. Pazzianotto. 100 anos de sindicalismo. São Paulo: Lex Editora, 2007.

POCHMANN, Marcio. Sindicalismo Patronal Brasileiro - Auge e Declínio. Revista São Paulo em Perspectiva, São Paulo, Fundação Seade, v. 12, no. 1, Jan-Mar, 1998.

ROLOW, Rafael; DE OLIVEIRA JOÃO, Jean Carlo. Uma metodologia para analisar as práticas percebidas de liderança: um estudo de caso no setor bancário. Revista Alcance, Itajaí, v. 16, n. 2, p. 260-277, 2009. DOI: http://dx.doi.org/10.14210/alcance.v16n2.p260-277

SANTANA, Marco Aurélio. Para onde foram os sindicatos? Caderno CRH, Salvador, v. 28, n. 75, p. 453-456, 2015. DOI: http://dx.doi.org/10.1590/S0103-49792015000300005.

SHRIVER, Sam; WILLIAMS, Brett. Situational leadership and cybersecurity. Leader to Leader, Atlanta, v. 2019, n. 91, p. 44-49, 2019. DOI: https://doi.org/10.1002/ltl.20409

RGO - Revista Gestão Organizacional, Chapecó, v. 12, n. 3, Edição Especial, p. 35-53, 2019. 
SILVA, Wendel Alex Castro; DE JESUS, Daiana Kelle Aragão; DE OLIVEIRA MELO, Alfredo Alves. Ciclo de vida das organizações: sinais de longevidade e mortalidade de micro e pequenas indústrias na região de Contagem-MG. REGE Revista de Gestão, São Paulo, v. 17, n. 3, p. 245263, 2010.

SILVA, Gustavo Melo; EMMENDOERF, Magnus Luiz. Ciclo de vida das organizações, empreendedorismo e liderança administrativa: contribuições e reflexões para os estudos organizacionais. Revista Ciências Administrativas ou Journal of Administrative Sciences, Fortaleza, v. 19, n. 1, 2014.

SMITH, Mike. Situational leadership training. Journal of management in engineer, Washington, v. 7, n. 4, p.365-374, Oct. 1991. DOI: https://doi.org/10.1061/(ASCE)9742-597X(1991)7:4(365)

THOMPSON, Geir; VECCHIO, Robert P. Situational leadership theory: A test of three versions. The leadership quarterly, Lausanne, v. 20, n. 5, p. 837-848, 2009. DOI:

https://doi.org/10.1016/j.leaqua.2009.06.014

TURANO, Lucas Martins; CAVAZOTTE, Flávia. Conhecimento científico sobre liderança: uma análise bibliométrica do acervo do The Leadership Quarterly. Revista de Administração Contemporânea, São Paulo, v. 20, n. 4, p. 434-457, 2016. DOI: http://dx.doi.org/10.1590/19827849rac2016140075.

WRIGHT, Erik S. Dialogic development in the situational leadership style. Performance Improvement, New York, v. 56, n. 9, p. 27-31, 2017. DOI: https://doi.org/10.1002/pfi.21733

YIN, Robert K. Estudo de Caso: Planejamento e métodos. Bookman editora, 2015. 